\title{
Challenges and policy lessons for the growth-employment-poverty nexus in developing countries
}

\author{
Gary S Fields
}

Correspondence: gsf2@cornell.edu Cornell University and IZA, Bonn, Germany

\begin{abstract}
Of the world's 6.7 billion people (as of 2008), 1.3 billion lived on less than $\$ 1.25$ Purchasing Power Parity dollars per person per day and another 1.7 billion lived on between \$1.25 and \$2.50 PPP dollars (Chen and Ravallion, 2012). The scourge of absolute economic misery among billions of the world's people is one of the most serious problems facing humankind today. Unemployment (defined below) befalls about 200 million of the world's people - a sizeable number but small compared to the three billion people who are poor using the \$2.50 PPP dollar poverty line. A much larger number - 900 million - are employed but earning so little that they and their families are unable to reach even $\$ 2$ per person per day (ILO, 2012). They are working hard and they are working poor. (Working Hard, Working Poor is the title of my latest book (Fields, 2012). To achieve more and better employment (where "better" depends on such factors as rate of pay, job security, employment protections, and type of work), analysts and donors need to understand better how employment, growth, poverty and other factors interact, how unemployment is caused, and how employment can be improved. At the same time, drawing on practical experience, research can identify knowledge gaps that to date pose limits to successful employment creation policy.
\end{abstract}

Keywords: Employment, Poverty, Economic growth, Foreign assistance, Developing countries

JEL classification: $13, \mathrm{~J} 2,01,019$

\section{Introduction}

\subsection{Context}

Of the world's 6.7 billion people (as of 2008), 1.3 billion lived on less than $\$ 1.25$ Purchasing Power Parity dollars per person per day and another 1.7 billion lived on between \$1.25 and \$2.50 PPP dollars (Chen and Ravallion, 2012). ${ }^{1}$ The scourge of absolute economic misery among billions of the world's people is one of the most serious problems facing humankind today.

Unemployment (defined below) befalls about 200 million of the world's people - a sizeable number but small compared to the three billion people who are poor using the \$2.50 PPP dollar poverty line. A much larger number - 900 million - are employed but earning so little that they and their families are unable to reach even $\$ 2$ per person 
per day (ILO, 2012). They are working hard and they are working poor. (Working Hard, Working Poor is the title of my latest book (Fields, 2012).

To achieve more and better employment (where "better" depends on such factors as rate of pay, job security, employment protections, and type of work), analysts and donors need to understand better how employment, growth, poverty and other factors interact, how unemployment is caused, and how employment can be improved. At the same time, drawing on practical experience, research can identify knowledge gaps that to date pose limits to successful employment creation policy.

\subsection{Some basic data}

Some research findings have been so clearly established that they form the knowledge base for the rest of this paper. Specifically:

- Most countries in the world have experienced economic growth (World Bank, 2012). Economic growth is positive in every geographic region of the world. It is positive in every income group (high income, middle income, and low income). And it is positive in $90 \%$ of the countries of the world.

- Most countries in the world have experienced falling poverty (World Bank, 2012).

- Economic growth and poverty reduction usually go together at the macro level

(Fields, 2001). Poverty has fallen in the great majority of country cases when economic growth has taken place. When poverty has not fallen, it typically is because economic growth has not taken place.

- Human development indicators have risen in every single country of the world (United Nations, 2011).

- In every country of the world, better-educated workers earn more on average than less-educated workers do (Psacharopoulos and Patrinos, 2004). Consequently, countless poverty profiles from around the world show lower rates of poverty among households whose heads are better educated.

- An important reason why better-educated workers earn more is that they work in better job categories than less-educated workers do (Schultz, 1988).

- Unemployment is particularly prevalent among youth (defined by the ILO as persons between the ages of 15 and 24). However, youth are only about $20 \%$ of the world's labor force (ILO, 2012).

- The world has an employment problem more than an unemployment problem. 200 million people in the world are unemployed, but an additional 900 million earn so little that they and their families are unable to attain a standard of living of even $\$ 2$ PPP dollars per day (ILO, 2012).

\subsection{How the poor are working}

The essence of developing countries' labor market problems is an insufficient number of "good jobs" for all who want to work in them and are capable of performing them. Workers in the poorer countries need to work, and so when no one else will hire them, they create their own earning opportunities, typically in very low-paying selfemployment, which has been graphically termed "reluctant entrepreneurship" (Banerjee and Duflo, 2011). Consequently, the unemployment rates in the developing countries 
are lower than those in the developed countries. The poor work long hours but earn so little per hour that they are unable to move above the poverty line. Besides their low earnings, most have few job-related social protections. Too many are in indecent work: modern-day slavery, indentured servitude, child prostitution, and the like. Women face particular disadvantages in the labor market.

These and other conditions are elaborated in Fields (2012, Chapter 4), to which the reader is referred for further information.

\section{The growth-employment-poverty nexus: changes over time in individual countries}

\subsection{The experiences of major developing economies ${ }^{2}$ \\ China $^{3}$}

Economic growth has brought about a sharp reduction in poverty. China combines the most rapid economic growth of any country in the world - 10\% a year in real terms with the largest reduction in poverty ever recorded: a reduction of 500 million persons in the quarter-century ending in 2005 living on less than $\$ 2.00$ per person per day. China's urban unemployment rate is now moderate, having fallen in the 2000s. Rural unemployment data are not available, so the unemployment figures for China are limited to urban areas. The official unemployment rate among local residents in urban areas ("registered unemployment") is $4.2 \%$. In addition, however, the urban unemployment has been estimated approximating the ILO definition - that is, including migrants as well as persons with urban household registration and workers in unregistered employment in addition to workers in registered employment in both numerator and denominator. This so-called "surveyed unemployment rate" (so called because it is based on household survey data) is found to be 5.2\% (Yang and $\mathrm{Gu}, 2010$ ). And when international methods are applied - that is, calculating unemployment as the difference between total employment and labor force and then calculating the unemployment rate as the ratio of unemployment to labor force China's urban unemployment rate is estimated to have peaked at nearly $10 \%$ in 2000 before falling to around 6\% by 2008 (Arnal and Förster, 2010).

For the most part, the mix of jobs has improved. Urban employment, which pays four times what rural employment does, engages a larger percentage of the labor force than previously. This is because of rural-to-urban migration, not because of birth rate differences; China continues to adhere rigidly to its one-child policy. Workers have been moving out of agriculture (a low-paying activity) and into manufacturing (especially in township and village enterprises) and services. Workers have also been moving out of self-employment and into wage employment. In all of these respects, then, the mix of jobs has improved. In one other respect, though, the job mix has worsened, at least from the point of view of workers: as a consequence of economic and labor market reforms, there was a sharp cut in public sector employment; these were the jobs with the highest pay, most generous benefits, and iron-clad job security.

Real labor earnings have increased sharply. Compared to 1995, real urban earnings are five times higher now and rural labor earnings nearly three times higher. Among formal sector workers, real wages rose rapidly overall, in each ownership type (state-owned 
enterprises, collectively-owned enterprises, and other ownership types), and in every region of China.

Household income inequality and labor income inequality have both increased. Urban labor incomes were twice rural labor incomes in 1995; they are now four times as high. Urban-rural earnings differentials persist after controlling for human capital variables. Migrants to urban areas earn only about half of what urban residents do. ${ }^{4}$ Overall, income inequality in China has been rising.

In summary: The Chinese labor market has played a central role in transmitting economic growth to workers, thereby reducing poverty. There have been huge improvements in many aspects of labor market conditions in the course of Chinese economic growth: reductions in unemployment, improved employment composition, rapidly rising real labor earnings. However, despite an enormous reduction in absolute poverty, income inequality in China is increasing; this issue is receiving a great deal of attention in Chinese policy circles at present.

\section{India ${ }^{5}$}

Indian economic growth is high and accelerating; the Indian economy was, until very recently, the second-fastest growing economy in the world (after China). The changes in labor market conditions in the course of Indian economic growth are as follows:

Low and falling unemployment. Using the definition of unemployment closest to the ILO's, the data show that India's unemployment rate stayed right around 3\% from 1983 to $2004 / 05$, then fell to $2.6 \%$ in 2009/10.

Composition of employment. Indian workers remain employed overwhelmingly in informal employment. As stated earlier, $86 \%$ of Indian workers are in the informal sector and another 7\% are informal workers in the formal sector; just 7\% of Indian workers are formal workers. Essentially all of the increase in employment in India has been in informal employment; but because the rate of informal employment is so high and the rate of formal employment so low to begin with, the shares of formal and informal employment in the total have barely changed.

As for other aspects of employment composition, over time, the composition of employment improved so that a larger percentage of the employed were in regular wage employment and casual wage employment and a smaller percentage in selfemployment. Still, though, 57\% of Indian workers are self-employed and $28 \%$ are casual wage employees. As for the composition of employment by economic sector, it too has changed, so that agriculture's share of the total fell and industry's share rose, consistent with a shift to higher-paying activities. (Services' share increased as well, but this change is not easy to interpret owing to the heterogeneity of the services sector.) However, because these changes have been rather slow, the structure of employment is not much different from what it was earlier. Agriculture's share fell from $64.9 \%$ of total employment to $54.6 \%$ over a twenty-year period; thus, agriculture remains the majority employer in India even now. The education level in India is improving, but it still remains very low: $50 \%$ of the female labor force and more than $20 \%$ of the male labor force have no education at all, and the education that is received remains highly variable in quality. 
Real wages. Where the main improvement in Indian labor market conditions has been recorded is in real wages. Positive wage growth was recorded between 1993/94 and 2004/05 for all sixteen employment groups analyzed. (The sixteen groups are rural male/rural female/urban male/urban female cross-classified by regular/casual and agriculture/non-agriculture.) Between 1993/94 and 2004/05, real wages grew at only about half the rate of growth of the economy as a whole; but between 2004/05 and 2009/10, real wages grew at about the same rate as the economy as a whole. Moreover, these wage increases were at about the same rate in regular wage employment, casual wage employment, and the informal sector; the only important group whose wages rose at a slower rate is formal sector workers.

Inequality. Income inequality in India has been rising. See, for instance, Asian Development Bank (2007) and ILO (2008).

Poverty. In India, the percentage of workers in households below a constant real absolute poverty line fell continuously, overall and for each employment status (regular wage and salaried workers, the self-employed, and casual labor).

In summary: Indian economic growth was rapid, labor market conditions improved, but the improvements in types of employment were slow compared to the rapid economic growth. In recent years, though, real wages in most employment categories have been rising apace of economic growth.

\section{Brazil $^{6}$}

In the period from 1996 to 2004, the Brazilian economy experienced real per capita economic growth of less than 1 percent a year, during which poverty increased. Given the importance of labor income in total income in Brazil as elsewhere, it would be expected that very slow economic growth and an increase in poverty would be accompanied by a mixed pattern of changes in the labor market, with some indicators registering an improvement and some a deterioration. Indeed, the data show exactly that.

There were signs of progress. They include an improved sectoral mix of employment, higher educational levels of the employed, a higher proportion of employed in wage and salaried employment, shorter weekly work hours, a reduced child work rate, higher participation in social security, and a reduction in unpaid work. Many of these changes were very modest in magnitude.

On the other hand, there were also signs of regress. Unemployment rose, median earnings fell, and earnings inequality rose for several groups. The percentage of workers holding signed labor cards and receiving the consequent employment protections fell further from an already low level.

In summary, important labor market problems remain in Brazil. They include high unemployment, low earnings, lack of participation in social security, lack of employment protection, and significant unpaid family work.

\section{Mexico $^{7}$}

Between 2000 and 2006, the Mexican economy grew at an average annual rate of 2.9\% in real terms. During this growth period:

Overall unemployment increased in Mexico by one percentage point from 2000 to 2006. However, the unemployment rate in 2006 was still very low: just 3.6\%. Mexico's chief labor market problem is not unemployment; it is low earnings. 
The composition of employment improved. Compared to 2000, a smaller percentage of Mexicans were working in the low-paying primary sector (agriculture and related activities) in 2006 and more in the higher-paying trade and services sectors. A larger percentage of workers had completed high school or above and a smaller percentage were illiterate. However, there was hardly any change in the sources of workers' earnings (wage and salaried employment, business, and other).

Real labor market earnings increased, overall and for most groups. Average real monthly earnings grew by $1.2 \%$, which was less than the growth rate of GDP. Wage and salaried workers' average monthly earnings rose, the average earnings of workers deriving their incomes from business declined, and the average earnings of workers with incomes from other sources rose. Earnings rose for both males and females. And they rose for workers in every economic sector (primary, trade, manufacturing, services, public sector, and other).

The poverty rates in Mexico fell using three different poverty lines, in both urban and rural areas.

Income inequality in Mexico fell. A Lorenz-improvement took place, and therefore all Lorenz-consistent inequality measures such as the Gini coefficient register falling inequality.

In summary: Mexican economic growth was accompanied by rising unemployment, improved employment composition, rising real labor earnings, and falling poverty and inequality.

\section{South Africa ${ }^{8}$}

Following the fall of apartheid in 1993, the South African economy grew at an average annual rate of nearly $3 \%$ in real terms in the next fifteen years. After adjusting for population growth, real per capita GDP averaged 1.4\% growth over that same period.

In terms of the labor market indicators identified in this report, we find:

Unemployment in South Africa rose dramatically in the first half of the period and started to fall only in the early 2000s. Using the standard international definition of unemployment (the ILO definition), the unemployment rate rose from 13.6\% in 1993 to $28.9 \%$ in 2001 before falling to $23.4 \%$ by 2008 . Another, broader definition of unemployment is commonly used in South Africa, including in addition persons who were not working, were not searching for work, but report that they are willing to take a job. The broad unemployment rate too rose in the earlier period (from $31.2 \%$ to $40.8 \%$ between 1993 and 2001) before falling to $28.9 \%$ by 2008 . Words like "frightful" and "catastrophic" are used to describe unemployment rates of such magnitudes. The exceptionally high unemployment rate in South Africa is accompanied by an exceptionally low rate of informal wage-employment and self-employment. Workers in South Africa have not responded to the lack of wage-employment opportunities by creating their own self-employment positions to the same extent as have workers in most other countries. In most developing countries, informal employment comprises about three-quarters of non-agricultural employment. In South Africa, the rate is onehalf. Among the barriers to creation of informal employment in South Africa are geographic separation of would-be self-employed from markets, crime, lack of access to infrastructure, lack of access to services, insufficient skills, hassles from the local 
authorities, harsh licensing requirements, and insufficient informal credit. Instead, the unemployed in South Africa have attached themselves to households with income from the labor market and/or social grants.

Various indicators of employment composition show a worsening job mix. Among those who are employed in South Africa, we find an increased rate of part-time and casual employment, a higher share of informal employment (defined as those working in a business that is not registered with the government, plus domestic workers), and a shrinking rate of wage and salaried employment as a percentage of total employment over time.

Real monthly wages grew, but in a very unequal way. Average wages increased overall and for most races (African, Indian, and white) but not for coloreds. ("Coloreds" is the South African term for persons of mixed race.) But real wages rose only in the top two labor income deciles; in the other eight, real wages fell. For the poorest decile, the decline was a stunning $43 \%$.

Household poverty rates fell, using the \$1.25 PPP dollar and \$2.00 PPP dollar poverty lines described above. The fall in poverty is due to South Africa's system of social grants and not to changes in the labor market. Despite the falling poverty rates, the percentages of South Africans recorded as poor using these poverty lines were respectively $17.7 \%$ and $30.0 \%$ in 2008 . The poor in South Africa are overwhelmingly non-white, reflecting the nation's legacy of apartheid.

Income inequality, already at a high level, increased even more. By 2008, the aggregate Gini coefficient of per capita income reached 0.70 , which is one of the very highest rates of inequality the world. This was caused in large part by the rising inequality of monthly wages, which was noted above.

In summary: Unlike in most other countries, in the case of South Africa, economic growth did not generally result in improved labor market conditions. Household poverty rates did fall, but not because of changes in the labor market.

\section{The five countries compared}

Table 1 presents a qualitative summary of the changes taking place in the five preceding countries. Rapid economic growth resulted in improved labor market conditions in China and India, while moderate and slow growth produced a mixed pattern of changes in South Africa, Mexico, and Brazil.

\subsection{Other countries}

A number of earlier studies had been carried out on the question of how labor market conditions changed with economic growth in other developing countries. Their main results are:

The World Bank's 'Working Out of Poverty' series: This project resulted in three country studies: Bangladesh (Paci and Sasin, 2008), Madagascar (Hoftijzer and Paci, 2008), and Nicaragua (Gutierrez, Paci, and Ranzani, 2008). Bangladesh achieved good economic growth, improved labor market conditions, and falling poverty. In Nicaragua, modest economic growth took place, but labor market indicators were mixed: employment grew primarily in the agricultural, manufacturing, and commerce 
Table 1 Economic growth and changing labor market conditions in five developing countries

\begin{tabular}{|c|c|c|c|c|c|}
\hline & $\begin{array}{l}\text { China, approx. } \\
\text { last } 25 \text { years }\end{array}$ & $\begin{array}{l}\text { India, approx. } \\
\text { last } 25 \text { years }\end{array}$ & $\begin{array}{l}\text { Brazil, } \\
\text { 1996-2004 }\end{array}$ & $\begin{array}{l}\text { Mexico, } \\
\text { 2000-2006 }\end{array}$ & $\begin{array}{l}\text { South Africa, } \\
\text { approx. last } \\
20 \text { years }\end{array}$ \\
\hline Economic growth & $\begin{array}{l}\text { Highest in the } \\
\text { world }\end{array}$ & $\begin{array}{l}\text { Second highest in the } \\
\text { world until recently }\end{array}$ & Slow growth & $\begin{array}{l}\text { Moderate } \\
\text { growth }\end{array}$ & $\begin{array}{l}\text { Moderate } \\
\text { growth }\end{array}$ \\
\hline Unemployment rate & $\begin{array}{l}\text { Decreased } \\
\text { (urban) }\end{array}$ & Low and falling & Rose & $\begin{array}{l}\text { Rose but } \\
\text { still very } \\
\text { low }\end{array}$ & $\begin{array}{l}\text { Sharp rise, } \\
\text { then slow fall }\end{array}$ \\
\hline Mix of jobs & $\begin{array}{l}\text { Fast } \\
\text { improvements }\end{array}$ & Slow improvements & $\begin{array}{l}\text { Mixed pattern } \\
\text { of changes }\end{array}$ & Improved & Worsened \\
\hline Real labor earnings & Sharp increase & $\begin{array}{l}\text { Positive for all labor } \\
\text { force groups }\end{array}$ & Median fell & Slow rise & $\begin{array}{l}\text { Rose, } \\
\text { unequally }\end{array}$ \\
\hline Income inequality & Large increase & Rose & $\begin{array}{l}\text { Rose for } \\
\text { several } \\
\text { groups }\end{array}$ & Fell & Rose \\
\hline Absolute poverty & Sharp decrease & Continuous fall & Increased & Fell & $\begin{array}{l}\text { Fell because of } \\
\text { social grants, } \\
\text { not changes in } \\
\text { labor market }\end{array}$ \\
\hline $\begin{array}{l}\text { Overall change in } \\
\text { labor market } \\
\text { conditions }\end{array}$ & $\begin{array}{l}\text { Generally, much } \\
\text { better }\end{array}$ & Improved slowly & $\begin{array}{l}\text { Mixed } \\
\text { changes }\end{array}$ & $\begin{array}{l}\text { Generally } \\
\text { positive }\end{array}$ & $\begin{array}{l}\text { Mixed } \\
\text { changes }\end{array}$ \\
\hline
\end{tabular}

Let us turn now to the more scattered evidence available for other countries.

sectors; real wages grew in some sectors but not others; and the poverty headcount did not change. In Madagascar, during a period when economic growth did not take place, the labor market record was mixed: unemployment rose, real earnings increased at the bottom and middle of the earnings distribution but not the top, and poverty fell. Sub-Saharan Africa (Fox and Gaal, 2008): The study focuses on six countries: Burkina Faso, Cameroon, Ghana, Mozambique, Senegal, and Uganda. GDP growth rates per capita ranged from $2.0 \%$ to $6.5 \%$ per annum over periods ranging from five to ten years. Wage and salaried employment increased in all six countries, albeit from very low levels. Agriculture continued to be the major sector of employment despite a declining share in all six countries. Labor earnings grew by the largest amount in Mozambique (which achieved the fastest economic growth of the six), by the next largest amount in Uganda (which achieved the second-fastest economic growth), and by lesser amounts in the slower-growing economies.

Turkey (Güder, 2006): Turkey experienced slow average economic growth during the 1988-2004 period. Some of these were positive economic growth years, some negative ones. Employment, real wages, poverty, and employment composition improved during the growth years and reversed when growth was negative.

Taiwan, Indonesia, Costa Rica, and Brazil (Fields and Bagg, 2003): This study reached the following principal findings:

- Economic growth has been the driving force leading to improved labor market conditions and therefore reductions in poverty.

- The faster the economic growth, the faster the fall in poverty.

- Economic growth brought about higher real wages, a movement to more productive and higher paying jobs, and a more educated labor force in each country. 
- The role played by the private sector as opposed to the public sector in the upgrading of labor market conditions varied from country to country.

- Economic growth is a critical means for improving employment and earning opportunities and thereby lowering poverty.

Hong Kong, Singapore, Korea, and Taiwan (Fields, 1994): During the rapid economic growth of these economies, full employment was generally maintained, job mixes were improved, real earnings were raised, and poverty rates were lowered. Labor market conditions improved in these economies at rates comparable to their rates of aggregate economic growth.

Barbados, Jamaica, and Trinidad and Tobago (Fields, 1984): Barbados and Trinidad and Tobago grew at just $1-2 \%$ per annum in per capita terms over the study period. In both these economies, unemployment remained in double digits, agriculture's share of total employment fell, and real wages rose. Meanwhile, Jamaica suffered a cumulative $26 \%$ fall in real per capita GNP over the study period. As a consequence, the unemployment rate more than doubled, real wages fell by $30 \%$, and poverty rates rose; the only positive change was an increase in the share of employment in the best occupations, apparently because of loss of employment in the poorer ones.

\subsection{A comment on "jobless growth"}

One hears much about the notion of jobless growth - specifically, the claim that in many cases economic growth takes place, yet employment does not increase. This hypothesis is not borne out by the data. Actually, the truth is quite the opposite.

In the case of India, data from the Indian Planning Commission, the National Sample Survey Organization, the National Commission for Enterprises in the Unorganised Sector, and other sources all show a continuous increase in employment. What has not increased is the rate of unemployment in India. There has been little improvement in the categories of jobs people are working in, so informal employment remains the norm, but real wages have risen in all job categories. Though the pace of improvement in the types of work performed has been disappointing, economic growth in India has not been jobless.

In the case of South Africa, government data show an increase in employment, followed by an equally sharp decrease. But upon further examination, what we see increased and then decreased in South Africa is formal employment. Not so for total employment in South Africa; it has increased throughout.

A new World Bank research study by Cho et al. (2012) examines data for 133 low and middle income countries and groups them into four clusters: middle income, rapid growth, and structural change; upper middle income, aging, and declining informality; very low income, young, balanced employment growth; and low income, young, slow productivity growth. In all four clusters, employment as per the ILO definition increased apace of labor force growth in every country but one, and in that one, labor force grew at the rate of $1 \%$ and employment at the rate of $0 \% .{ }^{9}$

In short, there are cases where economic growth has taken place and formal employment has increased slowly or even decreased. Yet, as the labor force has grown, so too 
has employment in other areas. "Jobless" is not only hyperbole; it reflects a limited understanding of what counts as employment and what doesn't.

\subsection{In summary}

What the evidence presented in this section has shown is that labor market conditions generally improve as economic growth takes place within countries. This is true in lowincome and in middle-income countries, in Asia, Latin America, and Africa, and in fast-growing and not-so-fast growing economies. Developing country labor markets have transmitted economic growth to workers in the lower parts of the income distribution and in the poorer employment categories, thereby reducing poverty. The mechanisms responsible include increasing paid employment so that workers engaged in low-paying self-employment can move into positions that pay better, raising the returns to self-employment for those who remain self-employed, upgrading education and skills, and improving labor market programs. The policies underlying these changes are detailed below.

It is worth highlighting what the data do not show. It is not the case in general that countries' economic growth comes at the expense of labor, either in the sense of workers as a whole being made poorer or in the sense of workers as a whole being left out.

Among the developing countries, the one important documented exception to the generalizations noted in this summary is South Africa. There, it was not the labor market that transmitted economic growth to the poor; rather, it was an expanded and more generous system of social grants that was responsible. In that case, it was the legacy of apartheid that brought non-labor-market mechanisms to the fore.

\section{Policies for creating better labor market outcomes ${ }^{10}$}

This section examines four causal channels for creating better labor market outcomes: growth, trade, and aid; harnessing the energies of the private sector; expanding paid employment; and increasing the returns to self-employment.

\subsection{Growth, trade, and aid}

The evidence reviewed in Section 2 leaves no doubt about the importance of economic growth for improved labor market outcomes. This is not to say that economic growth is all that matters for improved employment outcomes. Nor is it meant to say that economic growth matters just for employment outcomes; it matters as well for countries' ability to afford to create new social programs and expand existing ones. Rather, what I want to say is that economic growth matters importantly, and it should be pursued as part of an employment-enhancing development strategy.

But it also bears mention that in addition to the rate of economic growth, what also matters importantly is the kind of economic growth pursued in a country. Growth may or may not be oriented toward the poor. In those cases where an anti-poverty focus is chosen, growth policies may be oriented toward people as workers to a greater or lesser degree; these policies are described further below. Alternatively, the poor may be targeted as consumers and citizens and reached through public spending aimed at fulfilling basic needs. But unless one or both of these mechanisms are in place, the result 
may well be economic growth of a type from which the typical person derives little or no gain. ${ }^{11}$

As for international trade, there are some who say that in today's globalized world, labor must be repressed so that labor costs remain low and countries with low labor costs maintain their comparative advantages (if in fact they had them in the first place). I think this is far too pessimistic a position. Rather, I side with those such as Stiglitz and Charlton (2005) and Rodrik (2007) who maintain that if the trade environment is carefully managed, more open international trade can bring about better labor market outcomes and thereby reduce poverty. China is the most prominent example of a country that has achieved rapid export-led growth, rapidly-rising real wages, and an unprecedented reduction in poverty (see Section 3), but it is by no means the only one. Many countries in East and Southeast Asia and Latin America have also achieved high rates of economic growth, substantial export growth, and falling poverty (Asian Development Bank, 2007; ECLAC, 2011).

And then, there is the famous (and sometimes entertaining, sometimes depressing) debate about foreign aid and whether it makes things better or worse; see, for example, the controversy between Sachs (2005) and Easterly (2006). The richer countries have often stated that they aim to devote $0.7 \%$ of their GDPs to foreign aid; yet, the United States and Japan each devote just $0.2 \%$ of GDP to this cause. If an additional $0.5 \%$ of GDP were to be made available for foreign aid by the United States, Japan, and other well-to-do countries, many more worthwhile things could be done in the fight against global poverty. I am convinced that the benefits from doing these things outweigh the costs, which is why I favor increased aid. At the same time, I fully support the insistence of organizations such as the Bill and Melinda Gates Foundation and the Clinton Global Initiative on measurability and scalability of results in all that they do.

\subsection{Harnessing the energies of private companies}

Some ninety percent of developing country workers work in the private sector. Some of these ninety percent are wage and salaried workers who have regular contracts and enjoy social protections, but most are not. The majority are self-employed, casual workers, and/or outside the ambit of social protection, often in individual or household enterprises.

I think that the best way to understand what private companies do is to regard them as profit-seeking institutions. They will invest in a country or not, hire workers or not, pay them well or not, train them or not, adopt "high road" human resource policies or not, and make many other decisions based on what is in their profit-maximizing interest to do.

If I am right, the profit-seeking interests of companies act as a constraint on those policy-makers and organizations that seek improved labor market outcomes for workers. Improved labor market outcomes may be a by-product of profit-seeking on the part of firms, but I don't think it is realistic for improved labor market outcomes to be seen as a goal of private sector employers. Accordingly, public policies on the part of national and international organizations and private policies on the part of labor unions, other worker organizations, and non-governmental organizations (NGOs) need to be formulated in view of this reality. 
Private companies will want to hire the workers of a given country if they can make a higher profit by doing so than they can by hiring the workers of some other country or by hiring robots and very few workers. Although it has always been the case that businesses have had a choice about where to operate and which workers to hire, in today's globalized world, their range of choices is far greater. Laws, regulations, and other institutions need to be chosen accordingly.

The market-oriented liberalizations in China and India - in the memorable words of Deng Xiao Ping, "Black cat, white cat, all that matters is that it catches mice" - produced enormous gains for workers in those economies. Essentially, the private sector was set loose and the economy flourished (though not, it should be added, without some serious abuses and problems).

Finally, the role of journalistic investigation and consumer movements should not be underestimated. It may be in companies' enlightened self-interest not only to profess a concern for worker rights and working conditions, healthy products, honest dealings, and the environment but actually to act on that concern. Global companies including Nike, Citibank, Merck, Wal-Mart, Starbucks, Monsanto, Interface, and others have found that "principles pay" (Heal, 2008). As this paper is being finalized, Apple, Foxconn, and others are under enormous pressure to clean up their manufacturing practices and those of their suppliers (Duhigg and Bradsher, 2012; Fair Labor Association, 2012).

The actions of governments, NGOs, labor unions, student groups, and other civil society actors may well change what is in private companies' profit-maximizing interests to do. I don't think that foreign aid or other types of international development assistance will be made conditional on improved labor market practices, nor do I think that the ILO will gain any enforcement powers. At least for now, public pressure is likely to remain one of the most potent forces in inducing private companies to undertake proworker actions and reforms, along with ever-tightening labor markets and a consequent competition among employers for workers as discussed above.

\subsection{Generating more paid employment}

If policymakers in a country were to decide to prioritize the creation of more paid employment in the labor market, what might they do? International experience suggests a number of policy measures.

- Avoid prematurely high labor costs. By "prematurely high labor costs," I mean labor costs that are higher than they would have been if they had been set by supply and demand in the labor market. Countless studies from around the world show that higher labor costs result in lower employment - in the language of economics, the wage elasticity of demand for labor is negative. Higher wages, more generous benefits to workers, and greater labor market protections are good for other labor market objectives but they are not good for the objective of generating employment. Research on developing countries reveals a modest disemployment effect of minimum wages, and consequently a higher total wage bill (Freeman, 2010).

- Remove undue barriers to employment. Some countries such as India and South Africa have instituted stringent employment protection laws restricting dismissals of 
workers. Such seemingly pro-worker legislation can have a perverse effect: knowing that they cannot dismiss workers in the event of a business downturn or unsatisfactory job performance, firms are reluctant to hire workers in the first place. Studies have found lower employment and higher poverty as a result (e.g., Besley and Burgess, 2004; Bhorat et al., 2001; Leibbrandt et al., 2010).

- Increase employees' skills and productive abilities to the extent that skill deficiencies are causing job vacancies to go unfilled. We hear often that education and skills are the path to better employment opportunities and higher earnings. While any given individual may well be able to improve his/her labor market chances by acquiring greater education and skill, the argument does not extend automatically to an economy as a whole. Investing in education and skills may well be the right thing to do if positions offered by employers go unfilled because of a mismatch between the skills required by employers and the skills offered by would-be workers. (Whether it is the right thing to do or not depends on how the social benefits of education compare with the social costs in the setting in question.) But investing in skills and productive abilities may well be the wrong thing to do if employers are not hiring for other reasons such as lack of product market demand and if job-seekers are already holding out for jobs they deem suitable even if such jobs are not available. The last thing a poor country wants to do is invest in expensive education that generates more educated unemployment. Education-labor market linkages need to be explored carefully.

In those cases where investment in skills does seem warranted because of a shortage of workers with the desired skills, the question arises about how to do it. Mexico has a successful training program known by its Spanish acronym SICAT which provides for employers to offer training in skills they need such as lathe operating and air conditioner repairing. It may well be better to leave it to employers to decide in which occupations to offer training than for the Ministry of Labor to try to pick winners.

- Create jobs for the poor. So-called "workfare" programs have been tried in Argentina, Bangladesh, and the Indian state of Maharashtra (of which Mumbai is the capital), among others. By far the most ambitious of all is India's National Rural Employment Guarantee Act (NREGA). NREGA guarantees to each rural household at least one hundred days of wage employment a year. NREGA has registered some successes (most importantly, earnings for participants who would otherwise not be working) and also some problems (far fewer than one hundred days of work, plus "operational deficiencies" including skimming by corrupt officials and non-payment for work performed). The government of India is in the midst of a nationwide Unique Identification Number program which, when fully implemented, is expected to drastically reduce such corruption, not only in NREGA but throughout India.

- Do not use limited development resources to improve labor market information systems. Improved labor market information systems are designed to deal with one kind of circumstance - when employers want workers, workers want jobs, but the employers and workers cannot find one another. (Economists call this "frictional unemployment"). But agreement is widespread among labor economists that unemployment in developing countries is not frictional; it is either deficient demand 
(employers wanting to hire fewer workers than are available and qualified) or structural (whereby a mismatch exists between the types of workers employers want to hire and the types of workers available to be hired). Improved labor market information systems address a non-problem; scarce public resources should not be allocated to them.

\subsection{Increasing self-employment earnings}

As an alternative to prioritizing the creation of more paid employment in the labor market, a developing country might concentrate on raising the earnings of the selfemployed, which is how most of the poor are working. If this is the priority, what might be done?

- Design products to help raise the productivity of the self-employed. Organizations such as International Development Enterprises, D-Rev: Design for the Other 90\%, KickStart, and Fuel from the Fields design products to overcome constraints facing the poor. An example of such a product is a garden drip kit that irrigates twenty square meters at a cost of just $\$ 3$. Farmers who use this new system can earn much more per irrigated square meter than they could have without irrigation, then use the profits to buy more drip kits, irrigate more land, increase their profits, and so on. Another such product is a treadle pump resembling a Stairmaster that lifts water to the surface from up to seven meters below the ground. In Bangladesh, a cost-benefit calculation showed that a $\$ 50$ million investment in treadle pumps by donors and smallholders produced an annual net smallholder return on investment of $\$ 150$ million. Designing such products can be socially profitable in terms of earnings increases that far outweigh the costs.

- Adopt a positive policy stance toward the self-employed and avoid hassling them. Many more of the poor in developing countries are self-employed than wage employees. City councils in the major cities of South Africa spend a lot of money to stop "illegal, unlicensed street trading." What makes such street trading illegal is that not enough permits are issued for all would-be traders, forcing the majority of traders to operate without permits. This official hostility is anti-development. If the city councils were to recognize that most of the poor people living in their jurisdictions have no choice but to earn their livelihoods from street vending and other such selfemployment activities and were to therefore adopt a more positive policy stance (or at least a less negative one), the urban poor would have a better chance of earning their way out of poverty. The informal economy should be nurtured, not repressed.

- Provide the poor in agriculture with more to work with. The poor in agriculture are often poor because they lack land, but they are also poor for other reasons. It is common for them to also lack water, other inputs, knowledge of best practices, access to product markets, protection against risk, and access to financial services. To be able to invest in what works, the Bill and Melinda Gates Foundation commissioned the International Food Policy Research Institute to investigate which of more than 250 possible interventions are actually effective in achieving agricultural development. The study (Spielman and Pandya-Lorch, 2009) identified 20 interventions as "proven successes." They included the Green Revolution in Asia, improved maize in sub- 
Saharan Africa, pearl millet and sorghum in arid lands, connecting the milk grid in India, and land tenure reform in Vietnam. More and more, foundations and other development organizations are engaged in such evidence-based policy formulation. - Facilitate supplemental off-farm wage-employment and self-employment. Even among farm households, it is the norm to engage in more than one activity. Off-farm activities can be stimulated in a variety of ways: by investing in "hard infrastructure" such as roads and electrification and "soft infrastructure" such as banking systems and market information systems; by investing in general education and specific skills; and by providing greater access to credit and financial savings, on which more below. "Rural" should not be equated with "agricultural"; a prime example of successful rural development with a strong non-agricultural component is the case of Taiwan.

- Make capital available to the poor. The poor lack many kinds of capital. As a result, many worthwhile investments that would raise their earnings are not undertaken. Studies have shown monthly rates of return of $15 \%$ in the case of Mexico (McKenzie and Woodruff, 2006) and 5\% in the case of Sri Lanka (de Mel, McKenzie, and Woodruff, 2008). And yet when the poor can borrow, it often is at exorbitant interest rates: $4.69 \%$ per day in Chennai, India, about $40 \%$ per month in the Philippines, and $10 \%$ per month in much of the rest of the developing world. It does not have to be like this. The Grameen Bank in Bangladesh (which was awarded the Nobel Peace Prize jointly with its founder, Dr. Muhammed Yunus) charges borrowers $12-17 \%$ per year and enjoys an almost 100\% repayment rate. The government of the Indian state of Andhra Pradesh (which, with 80 million people, would be the fourteenth most populous country in the world if it were a country) has arranged for banks to lend to groups of women at the rate of $12 \%$ per year; moreover, groups that repay their loans in full and on time pay just a 3\% per year interest rate, the government paying the bank the other 9\%. I regard microcredit as one of the best and most cost-effective ways known to create opportunities for the poor to build up their own businesses and earn their way out of poverty.

- Build skills and business know-how. In East Africa, the majority of micro and small entrepreneurs have at most primary education. They lack not only basic education and life skills but also basic business skills such as the fundamentals of operating and managing a business, saving safely, obtaining credit, learning new technologies, and knowledge about market opportunities. Many organizations are now involved in developing business know-how. They include: the ILO through its Workers Activities Programme (ACTRAV); companies such as Coca-Cola Sabco and Goldman Sachs; worker organizations such as the Self-Employed Women's Association (SEWA) of India; and government programs such as PAFPA in Côte d'Ivoire and the Foundation for International Community Assistance in Peru. Evaluation studies of programs like this typically show increased earnings for certain groups of participants, though not all. However, for the most part, cost-benefit comparisons have not been made.

- Stimulate microfranchising. Microfranchising brings together entrepreneurs who wish to expand their businesses with people who seek to operate their own selfemployment businesses but may not have the business know-how. The Grameen Bank operates a village phone program in Bangladesh and the Grameen Foundation a similar program in Rwanda. Village phone ladies (nearly all microfranchisees are women) are provided a loan enabling her to buy a cell phone business in a box which 
includes the phone itself and instructions on how to operate the phone, charge customers for minutes, and otherwise make the business a success. Other examples of microfranchising businesses are VisionSpring, which makes available low cost eye exams and affordable reading glasses in El Salvador, India, and Guatemala, and Honey Care Africa, which sets up beekeepers with hives, loans, training, extension services, and a guaranteed market for their honey at fair trade prices.

\subsection{In summary}

This section has highlighted four groups of policy interventions - growth, trade, and aid; harnessing the energies of private companies; generating more paid employment; and increasing self-employment earnings - suggesting specific policy actions within each. No one policy instrument is enough. To stimulate the growth-employment-poverty nexus, no policies should be excluded a priori (nor included a priori either).

\section{Issues and guidelines for policy engagement}

This section tackles four major issues. First, in confronting and meeting the employment and development policy challenges identified above, it would be helpful for donors and policy-makers to set their own objectives and confront tradeoffs explicitly. Second, returning to the five countries highlighted in Section 3 - China, India, Brazil, Mexico, and South Africa - I present a brief characterization of each country's approach to development and offer provisional suggestions based on that country's experience for other, similar types of countries. Third, I pose a number of key questions for policyrelevant research, all of which have at most only partial and scattered answers for the developing countries of the world. And fourth, I present some concluding thoughts.

\subsection{Setting objectives and facing tradeoffs}

Too often, so-called "policy implications" are offered without specifying an explicit welfare criterion or criteria, posing a well-formulated model (or even a not-so-well-formulated model), or a specific statement about what policy instruments are or are not under consideration. This is at least as much of a problem in the employment area as it is in any other of development.

To try to overcome this objection, it is important to set objectives and face tradeoffs. One presumed objective of development is to help the poor. How to help the poor is open to discussion. Let us assume that helping the poor through improving their employment opportunities is an agreed-upon goal. Let us be clear, though, that helping the poor may not be the only goal of development policy; helping others in other parts of the income distribution or members of target groups may also be an important development goal. And let us also be clear that improving employment opportunities for the poor may not be the only means of helping them; helping the poor through improving and spreading social programs may be another means, for example.

The international community has highlighted four objectives for labor market policy. One is to expand employment opportunities. A second is to increase the earnings of workers so that they and their families can achieve socially acceptable living standards. A third is to protect workers against the loss of jobs or labor market earnings more generally. And a fourth is to insure respect for core labor standards in the workplace. 
Put differently, labor market well-being is a function of four arguments - employment opportunities, worker's earnings, protection against earnings loss, and respect for core labor standards - and is increasing in each of these arguments. Maximizing such a function is different from addressing a specific problem such as trying to reduce youth unemployment or raise the wages of low-skilled workers.

When there are multiple objectives like these, tradeoffs are likely, both on the policy side and on the budgetary side. On the policy side, a policy action that may be beneficial for one policy objective might work directly against the attainment of another policy objective. Raising a minimum wage, for example, might raise the earnings of those who are employed but reduce employment and hence earning opportunities for those who do not keep their jobs or do not get jobs in the first place. Those at higher levels of policy-making - in this case, it might be the ministry of labor - may then have to decide which is the more pressing goal in a given country context: to raise the earnings of the employed or to increase employment.

Meanwhile, on the budgetary side, the poorer the country, the more limited are the resources for such policy interventions. Resource scarcity makes it incumbent upon policy-makers to pose the core question of economics - how to allocate scarce resources among alternative uses - in the particular context in which they are dealing. Continuing with the question of how to allocate scarce resources among alternative uses in the labor market area, the scarce resources could be allocated for direct public sector employment creation, tax breaks for employment creation in the private sector, education and training, or a whole host of other actions in the labor market or bearing on the labor market. But helping the poor may take a completely different form: subsidizing food or housing, running programs for children and pregnant women, and the like. A higher-level authority such as a ministry of planning may need to adjudicate between these several competing claims on the limited available resources.

In making such decisions, it is not enough just to say that expenditures in a given area are meritorious; they need to be more meritorious than other expenditures. It is not enough just to say that actions in a given area benefit the beneficiaries of the program; the concern needs to be with social benefits to all members of society, not just those members of society who participate in the program in question. And it is not enough just to look at benefits; equal attention needs to be paid to costs, both the direct costs of the action under consideration but also the opportunity cost - that is, what will not be undertaken, because this program is undertaken.

What I have just described are some of the questions that would need to be asked and answered in a solid social cost-benefit analysis. I maintain that although it is hard to answer these questions well, it is better to answer the right questions approximately than the wrong questions exactly. ${ }^{12}$

\subsection{Some provisional conclusions regarding policy ${ }^{13}$}

The sponsors of this research have requested conditional conclusions about what policy measures would be most helpful for improving labor market conditions and thereby reducing poverty in countries of different types. The suggestions that follow are necessarily speculative, offered in the spirit of "If I had to decide right now what might be the highest priority interventions for a developing country most closely resembling China 
or India or Brazil or Mexico or South Africa, what features of the country's development approach are most salient and what do these features suggest would be priority policy interventions?"

Starting with China, no country matches China in population size (only India comes close), and no country has achieved China's record of rapid and sustained economic growth. As we all know, China's economic growth has been led by its manufacturing sector. Based on the prior experience of Japan, the later experiences of the "Asian tigers" (Hong Kong, Singapore, South Korea, and Taiwan), and the concurrent efforts of the "Asian cubs" (Indonesia, Malaysia, the Philippines, and Thailand), China saw the opportunity to improve conditions for its workers by embodying their labor in products manufactured for export to the rest of the world. China rightly figured that goods that were world class in quality and competitive in price would find ready markets, especially in the developed countries, whose purchasing power is the greatest. Not only did they harness the energies of capitalists within China and in the Chinese diaspora but they also attracted direct foreign investment on a massive scale. Besides being so numerous, Chinese labor is hard-working, well-educated, and increasingly English-speaking. Despite the rising real earnings in China and the so-called "labor shortages" - which are actually signs of companies' resistance to paying ever-rising wages - multinational companies are producing in China and hiring workers there precisely because production conditions are better there than just about anyplace else.

What other countries can learn from this experience is that they too can endeavor to make conditions attractive so that private firms will want to invest in their countries as well (or instead) and engage their workers to produce for the world market. Many countries have done this, including neighboring Vietnam, which has been particularly successful in improving labor market outcomes and reducing poverty at an impressive rate.

China (and later Vietnam) instituted major economic reforms; the four economic liberalizations introduced in China under the leadership of Deng Xiao Ping included liberalization of agriculture, industry, technology, and defense and were aimed at opening the country to foreign investment, the global market, and private competition. To succeed with such an outward-oriented development strategy in other countries, development officials need to ask hard-headed questions about what advantages and disadvantages their country offers, build on their advantages, and remedy some of the disadvantages.

Turning now to the experience of India, that country too embarked on a program of market-oriented liberalization. The main elements of India's economic liberalization were greater reliance on the private sector, opening up to foreign trade and foreign direct investment, reorienting government activities to those that the market was unlikely to perform well, and ensuring macroeconomic balance and a well-run financial sector

We all know that India is a country of great cities: among them, Delhi, Mumbai, Kolkata, and Chennai. We know of its world class information and communication technology (ICT) and business process outsourcing (BPO) enterprises in cities like Bangalore and Hyderabad. And we know that it produces more university graduates each year than the United States.

Yet, formal wage employment in cities constitutes a very small part of India's labor market. Some $85 \%$ of Indian workers are self-employed or in casual employment. The 
average educational attainment is low, even by developing country standards, and only a tiny fraction of those educated meet international quality standards - only $3 \%$ according to some reports. ${ }^{14}$ And India remains a predominantly rural country; a majority of its workers are still in agriculture.

A fundamental decision being faced by India and other countries at similar levels of development (India is now classified as a lower-middle income country, a group which also includes Egypt, Indonesia, the Philippines, and Vietnam, among others) is whether to try to use scarce development resources to help the poor where they are or to help get them out of where they are. If India were to try to help the poor get out of where they are, they could try to improve employment conditions by directly employing the poor in public sector jobs or by stimulating private sector firms to employ more workers or to employ non-wage workers in the public sector. To create wage jobs for even a fraction of India's self-employed would require massive expenditures, far exceeding the nation's means.

It appears that a more cost-effective alternative - the one India has in fact chosen - is to help the poor earn more in places where the poor now are. One way in which this is being done is through low-cost loans for the self-employed and household enterprises most impressively, the self-help group-bank linkage model in Andhra Pradesh cited above. Another way in which the poor in India are being helped in the geographic locales where they already are is through India's National Rural Employment Guarantee Act, also discussed above, which provides 100 days of off-farm employment in rural areas to any household which shows up to take advantage of it. Such low-cost, self-targeted interventions hold considerable promise for other low- and lower-middle-income countries which, like India, have masses of self-employed people and relatively few wage employees.

Turning to upper-middle-income countries, Section 3 also highlighted Brazil, Mexico, and South Africa. These three countries are at similar stages of economic development and face similar challenges. Their workers are caught in the middle: they find it difficult to compete on cost terms with workers in poorer countries like China and India, and they also find it difficult to compete with workers in the richer OECD countries in terms of productivity.

Comparative advantage has shifted significantly in these countries. Mexico has some unique advantages: it is the only developing country that borders the United States, plus it is part of the long-standing North American Free Trade Agreement. And yet, manufactures that had been produced and/or assembled in Mexico ten years ago - including telephones, PC monitors, transistors, vacuums, hard discs, and many others - are not made there any longer: most have moved to China (Carrillo, 2010). Mexican firms are succeeding with new products - avocados, for example. For its part, Brazil has faced the rise and fall of its furniture industry. Nowadays, Brazilian firms are succeeding with different new products: among them, jet aircraft, soybeans, and pork (Sabel et al., 2012). South Africa has become a major exporter of fruits and vegetables during the northern hemisphere's winter season. The point is that comparative advantage changes, and for middle-income countries to succeed (and low-income countries too), they need to be prepared to change along with it.

Most middle-income countries have high rates of wage employment relative to selfemployment and high rates of self-employment relative to unemployment. In Brazil, for example, there are twice as many wage employees as there are other employed persons; in turn, there are three times as many self-employed in Brazil as there are unemployed 
(Fields and Raju, 2007). Traditionally, Mexico has maintained a low rate of unemployment, averaging $3.6 \%$ over the last twelve years, and a high rate of self-employment. South Africa is very much an outlier in this respect: there, the number of selfemployed and the number of unemployed are about equal.

These different rates of wage employment, self-employment, and unemployment suggest different policy emphases in these countries and others like them. First, in countries with high rates of self-employment, an intervention that is likely to be cost-effective is to enable microenterprises to borrow at low cost, perhaps along the lines of the self-help group-bank linkage program in the Indian state of Andhra Pradesh, described above. Second, when skills are in short supply, it may be cost-effective for government to fund skills development in areas in which employers have effective demand, much as is being done under the SICAT program in Mexico. Third, government may be in a position to increase the demand for labor by encouraging the development of export industries, much as the government of China has done, or the development of export services, much as the government of India has done. (Note: developing exports does not necessarily mean unfettered openness to imports.) But because China is now half urban and half rural, whether to develop urban-based export industries and services or to develop rural China, which is much poorer, is itself an issue of intense discussion. Fourth, in those cases such as South Africa where powerful forces push strongly for high wages, generous benefits, and strong job protections which are only available for a small fraction of the work force ("the insiders"), government can launch a national dialogue assuring that the voices of the self-employed and the unemployed ("the outsiders") are also heard. ${ }^{15}$

Finally, my experience suggests some things which in general should not be done. One is general tax cuts and subsidies. They are unfocused and untargeted, and therefore unlikely to be cost-effective. Targeted and self-targeted programs such as conditional cash transfers would probably be better in this respect. A second is that it may be important to invest in education and training in a country, but the rationale for such investment should not be that workers with more education and training earn more than workers without. A better rationale would be to conduct a social cost-benefit analysis to determine whether the economy as a whole would be more productive if the labor force were better educated and trained (and in what ways) and whether the gain in economy-wide productivity outweighs the gain in economy-wide costs of producing the additional education and training. And third, improved labor market information systems are unlikely to increase employment - what they are likely to do in a typical developing country context is reallocate existing employment opportunities to those individuals with more labor market information from those with less. It is by no means obvious why the limited funds available for employment programs should be used in this way.

In choosing among these and other policy alternatives, please bear in mind the message presented above: that policy decisions should be based on comparisons of social benefits and social costs for alternative interventions. The best use of scarce development resources varies from place to place and circumstance to circumstance.

\subsection{Identifying and remedying critical knowledge gaps}

Based on this review as well as other investigations, I would highlight six priority areas for policy-relevant research in the low and middle income countries of the world. Within each, I highlight what I think is one particularly important question. 
Among the methods that might be used to answer these questions are tabulations and other descriptive methods, ordinary least squares regressions, instrumental variables estimation, panel data and panel data methods, mixed qualitative and quantitative methods, empirically-based theoretical models, and field studies to supplement quantitative desk work. Statistical/econometric studies and experiments both have an important place in learning what matters.

1. Growth and labor market outcomes

Priority question: To what extent does macroeconomic growth improve labor market conditions? Through what channels?

2. Demand for labor Priority question: Why is the labor demand curve in a country positioned where it is - that is, why do employers demand as much or as little labor as they do?

3. Supply of labor Priority question: What are the effects of various policy interventions on those treated and on those not treated?

4. Wage-setting mechanisms and institutions

Priority question: Using panel data, what are the patterns of earnings changes and their determinants? Why does the qualitative picture coming out of panel data analysis look so different from that found from analyzing comparable cross sections?

5. Other institutions impinging upon labor market functioning Priority question: Are there significant barriers to labor market adjustments a) within labor markets and b) outside of labor markets but impinging upon labor markets?

6. Interrelationships among labor markets Priority question: In some cases (e.g., China, India, South Africa, Mexico), none of the existing multisector labor market models captures the essential structure. What would be a better stylization in such cases?

\section{In conclusion}

Given the development community's focus on poverty reduction as being at the core of development policy and given also the demonstrated importance of labor earnings for poverty reduction, it is lamentable that the development banks, national aid agencies, and other development organizations have not devoted more attention to research on employment, earnings, and the functioning of labor markets.

Much of the existing research, compilations of data sets, and policy work is organized along regional lines. In Africa, for example, household surveys exist for thirty-six countries, of which Benin, Ethiopia, Gabon, Morocco, South Africa, Tanzania, and Zambia have more than one year of data available. The growth-employment-poverty nexus could be analyzed in these countries, but for the most part has not yet been (Bhorat, 2012). A wealth of household surveys for Latin American countries is available at the World Bank, the Inter-American Development Bank, and CEDLAS, a research institute in Argentina. The Asian Development Bank performs a similar role for Asia.

But despite the similarities within geographic regions, it seems to me that there are even more similarities in lessons for the growth-employment-poverty nexus by looking 
at countries at similar levels of development in different parts of the world. Brazil has more to learn from other far-away middle-income countries such as Malaysia than it does from its low-income neighbor, Bolivia. Bolivia has more to learn from such faraway low-income countries as Haiti, Bangladesh, and Ethiopia than it does from its much richer neighbors Peru, Chile, Argentina, Paraguay, and Brazil. The Dominican Republic can learn more from Mauritius in far-away Africa than it can from Haiti, with which it shares an island. And so on.

The reason I suggest looking for lessons from countries at similar levels of development, wherever in the world they might be, is that the level of development is a central determinant of which policy issues are important in which places. Research on India should be focused on the $85 \%$ of workers who are self-employed or casual wage employees: how to get them out of self-employment and casual wage employment and how to raise their earnings within their present job statuses if they have no choice but to remain there. But most of the labor market research I have seen on India concerns the other $15 \%$ of workers, those who are regular wage employees. In China, on the other hand, the balance should be different; because the country is now half-urban, half-rural, so the attention of the Chinese government, development organizations, and the research community should be divided roughly equally between urban issues and rural ones.

Let us try to draw policy prescriptions when our knowledge permits us to but be humble enough to acknowledge when our judgments are driven by hunches rather than hard facts. This paper will have succeeded if it has suggested some fruitful ways of making aid more targeted and closing the knowledge gap in the near future.

\section{Endnotes}

${ }^{1}$ The number living on less than \$1.25 PPP dollars per day is reported in Chen and Ravallion (2012). I thank Shaohua Chen for providing me with a specialized POVCAL run estimating the number in the $\$ 1.25-\$ 2.50$ range.

${ }^{2}$ These countries are chosen because of their importance and the availability of data.

${ }^{3}$ The following data on China come from Tao (2006), Cai and Du (2006), Cai and Wang (2010), Yang, Chen, and Monarch (2010), and Song (2012).

${ }^{4}$ According to China's residential registration system ("hukou"), all persons are classified as either "urban residents" or "rural residents." A "rural resident" who migrates to an urban area remains classified as rural unless that person is able to negotiate the difficult process of transferring his/her registration from rural to urban.

${ }^{5}$ The data in this section come from National Commission for Enterprises in the Unorganised Sector (2009), Ghose (2011), and World Bank (2011).

${ }^{6}$ The data for Brazil come from Fields and Raju, (2007).

7 The data for Mexico come from Rangel (2009).

8 The data for South Africa come from Kingdon and Knight (2008), Banerjee, Galiani, Levinsohn, McLaren, and Woolard (2008), and Leibbrandt, Woolard, McEwen, and Koep (2010).

${ }^{9}$ The paper does not identify that country or any other country by name.

10 The material in this section is drawn from Fields (2012, Part Two).

${ }^{11}$ In this unhappy category, I would place the Philippines under Marcos and the United States in the last fifteen or so years. For more on the choice of type of growth 
and consequences for poverty and employment, see Fields (1980, Chapter 6) and Fields (2001, Chapter 10) for developing countries and Tavernise (2011) and Stiglitz (2012) for the United States.

${ }^{12}$ See also Rosenzweig (2012).

${ }^{13}$ Some of the major citations on which this section is based are Bardhan (2010) on China and India, Lin (2012) on China, Ahluwalia (2007) and Kotwal, Ramaswami, and Wadhwa (2011) on India, and Dollar, Glewwe, and Agrawal (2004) on Vietnam.

${ }^{14}$ See, for example, Anand (2011) and Reddy (2012).

15 Two particularly good books reviewing the experimental evidence in these and other areas of development are Banerjee and Duflo (2011) and Karlan and Appel (2011).

\section{Competing interests}

The IZA Journal of Labor Policy is committed to the IZA Guiding Principles of Research Integrity. The author declares that he has observed these principles.

Author's information

This paper was completed before the author had access to the World Bank's 2013 World Development Report on Jobs.

\section{Acknowledgements}

This paper is based on a lecture delivered at the Conference on Employment and Development: What Do We Know and What Can We Do?, IZA and the German Development Bank (KfW), Berlin, March, 2012. The author gratefully acknowledges the generous financial support provided by the KfW and IZA for this work.

Responsible editor is David Neumark.

Received: 23 July 2012 Accepted: 30 August 2012

Published: 22 November 2012

\section{References}

Ahluwalia MS (2007) Planning, in Kaushik Basu, ed., The Oxford Companion to Economics in India. Oxford University Press, New Delhi

Anand G (2011) India Graduates Millions, but Too Few Are Fit to Hire. Wall Street Journal, April, 5

Arnal E, Förster M (2010) Growth, Employment and Inequality in Brazil, China, India and South Africa: An Overview, in Elena Arnal and Michael Förster, eds., Tackling Inequalities in Brazil, China, India, and South Africa. OECD, Paris

Asian Development Bank (2007) Key Indicators 2007. Asian Development Bank, Manila

Banerjee A, Duflo E (2011) Poor Economics. Public Affairs, New York

Banerjee A, Galiani S, Levinsohn J, McLaren Z, Woolard I (2008) Why Has Unemployment Risen in the New South Africa? Econ Transit 16(4):715-740

Bardhan P (2010) Awakening Giants: Feet of Clay. Princeton University Press, Princeton

Besley T, Burgess R (2004) Can Labor Regulation Hinder Economic Performance? Evidence from India. Q J Econ 119 (1):91-134

Bhorat H, Leibbrandt M, Maziya M, van der Berg S, Woolard I (2001) Fighting Poverty: Labor Markets and Inequality in South Africa. University of Cape Town Press, Cape Town

Bhorat H (2012) What Are the Most Important Research Questions on the Economics of Growth and Labour Markets in Low-Income Countries? University of Cape Town, processed

Cai F, Du Y (2006) Changing nature of rural poverty in China and new policy orientation. Chin Econ 39(4)

Cai F, Wang M (2010) Growth and structural changes in employment in transition China. J Comp Econ 38:71-81

Carrillo J (2010) The Maquila model in Mexico: industrial upgrading or downgrading? Presentation at Cornell University

Chen S, Ravallion M (2012) An Update to the World Bank's Estimates of Consumption Poverty in the Developing World. World Bank, Washington

Cho Y, Margolis D, Newhouse D, Robalino D (2012) Labor Markets in Middle and Low Income Countries: Trends and Implications for Social Protection and Labor Policies. World Bank Social Protection \& Labor Discussion Paper No. 1207

de Mel S, McKenzie D, Woodruff C (2008) Returns to capital in microenterprises: evidence from a field experiment. Q J Econ 123(4):1329-1372

Dollar D, Glewwe P, Agrawal N (2004) Economic Growth, Poverty, and Household Welfare in Vietnam. World Bank, Washington

Duhigg C, Bradsher K (2012) How the U.S. Lost Out on iPhone Work. The New York Times, January 21

Easterly W (2006) The White Man's Burden. Penguin Books, New York

ECLAC (United Nations Economic Commission for Latin America and the Caribbean) (2011) Social Panorama of Latin America. ECLAC, Santiago

Fair Labor Association (2012) Independent Investigation of Apple Supplier. Report Highlights, Foxconn, Available online at www.fairlabor.org 
Fields GS (1980) Poverty, Inequality, and Development. Cambridge University Press, New York

Fields GS (1984) Employment, Income Distribution and Economic Growth in Seven Small Open Economies. Econ J 94 (373): $74-83$

Fields GS (1994) Changing labor market conditions and economic development in Hong Kong, the Republic of Korea, Singapore, and Taiwan, China. The World Bank Economic Review 8(3):395-414

Fields GS (2001) Distribution and Development: A New look at the Developing World. MIT Press and Russell Sage Foundation, Cambridge, MA and New York

Fields GS (2012) Working Hard, Working Poor: A Global Journey. Oxford University Press, New York

Fields GS, Bagg WS (2003) Long-Term Economic Mobility and the Private Sector in Developing Countries: New Evidence, in Gary S. Fields and Guy Pfeffermann, eds., Pathways out of Poverty. Kluwer, Boston

Fields GS, Raju D (2007) Assessing Current and Changing Labor Market Conditions in Brazil, Report prepared for the World Bank, processed

Fox L, Gaal MS (2008) Working Out of Poverty: Job Creation and the Quality of Growth in Africa. World Bank, Washington

Freeman RB (2010) Labor Regulations, Unions, and Social Protection in Developing Countries: Market Distortions or Efficient Institutions? In: Rodrik D, Rosenzweig M (eds) Handbook of Development Economics, Volume 5. Elsevier, Amsterdam

Ghose A (2011) Employment: The Faultline in India's Emerging Economy, Paper presented at the Workshop on Employment - Global and Country Perspectives. New York University, September, 2011

Güder G (2006) Changing Labor Market Conditions and Economic Growth and Crisis in Turkey, Korea and Mexico. Unpublished Masters thesis, Cornell University

Gutierrez C, Paci P, Ranzani M (2008) Making Work Pay in Nicaragua. World Bank, Washington

Heal G (2008) When Principles Pay. Columbia Business School, New York

Hoftijzer M, Paci P (2008) Making Work Pay in Madagascar. World Bank, Washington

International Labor Organization (ILO) (2008) World of Work Report 2008. ILO, Geneva

International Labor Organization (ILO) (2012) Global Employment Trends. ILO, Geneva

Karlan D, Appel J (2011) More Than Good Intentions. Dutton, New York

Kingdon G, Knight JB (2008) Unemployment: South Africa's Achilles Heel, in Janine Aron, Brian Kahn, and Geeta Kingdon, eds., South African Economic Policy under Democracy. Oxford University Press, Oxford

Kotwal A, Ramaswami B, Wadhwa W (2011) Economic Liberalization and Indian Economic Growth: What's the Evidence? J Econ Lit 49(4):1152-1199

Leibbrandt M, Woolard I, McEwen H, Koep C (2010) Better Employment to Reduce Inequality Further in South Africa, in Arnal E and Lin JY, (2012). New Structural Economics. The World Bank, Washington

McKenzie DJ, Woodruff C (2006) Do Entry Costs Provide an Empirical Basis for Poverty Traps? Evidence from Mexican Microenterprises. Economic Development and Cultural Change 55:3-42

National Commission for Enterprises in the Unorganised Sector (2009) The Challenge of Employment in India: An Informal Economy Perspective. Academic Foundation, Delhi

Paci P, Sasin M (2008) Making Work Pay in Bangladesh. World Bank, Washington

Psacharopoulos G, Patrinos H (2004) Returns to investment in education: a further update. Educ Econ 12(2):111-134

Rangel E (2009) Have the Poor in Mexico Benefited from Economic Growth in Mexico from 2000 to 2006? Unpublished Masters thesis, Cornell University

Reddy RR (2012) Poor Quality of Engineers in India. The Hindu

Rodrik D (2007) One Economics, Many Recipes: Globalization, Institutions, and Economic Growth. Princeton University Press, Princeton

Rosenzweig MR (2012) Thinking Small: A Review of Poor Economics: A Radical Rethinking of the Way to Fight Global Poverty by Abhijit Banerjee and Esther Duflo. J Econ Lit 50(1):115-127

Sabel C, Fernández-Arias E, Hausmann R, Rodríguez-Clare A, Stein E (eds) (2012) Export Pioneers in Latin America. InterAmerican Development Bank and Harvard University, Washington and Cambridge

Sachs J (2005) The End of Poverty. Penguin Books, New York

Schultz TP (1988) Education Investments and Returns. In: Chenery H, Srinivasan TN (eds) Handbook of Development Economics. North Holland, Rotterdam

Song Y (2012) Central Features of the Current Chinese Labor Market. Cornell University, processed

Spielman DJ, Pandya-Lorch R (2009) Millions Fed: Proven Successes in Agricultural Development. International Food Policy Research Institute, Washington

Stiglitz JE (2012) The Price of Inequality. Norton, New York

Stiglitz JE, Charlton A (2005) Fair Trade for All. Oxford University Press, Oxford

Tao R (2006) The Labor Market in the People's Republic of China: Development and Policy Challenges in Economic Transition, in Jesus Felipe and Rana Hasan, eds., Labor Markets in Asia: issues and Perspectives. Asian Development Bank, Manila

Tavernise S (2011) Percentage of Americans Living in Poverty Rises to Highest Level Since 1993. The New York Times United Nations (2011) Human Development Report 2011. United Nations, New York

World Bank (2011) More and Better Jobs in South Asia. World Bank, Washington

World Bank (2012) World Development Report 2012. World Bank, Washington

Yang DT, Chen WW, Monarch R (2010) Rising Wages: Has China Lost Its Global Labor Advantage? Pac Econ Rev 15 (4):482-504

Yang Y, Gu Y (2010) Registered Unemployment versus Surveyed Unemployment in China. In: Jianmin L (ed) Chinese Labor Market: Perspectives, Problems and Solutions. (Nankai University Press)

doi:10.1186/2193-9004-1-6

Cite this article as: Fields: Challenges and policy lessons for the growth-employment-poverty nexus in

developing countries. IZA Journal of Labor Policy 2012 1:6. 